\title{
Optimum conditions for uricase enzyme production by Gliomastix gueg
}

\author{
Atalla M. M., ${ }^{1}$ Farag, M. M., ${ }^{2}$ Eman, R. H., ${ }^{1}$ Abd-El-Lataif, M. S. ${ }^{2}$ and Nehad E. A. ${ }^{1}$ \\ ${ }^{1}$ Department of Microbial Chemistry Products, National Research Center (NRC), Dokki and ${ }^{2}$ Depatment of Biochemistry, \\ Faculty of Agriculture, Cairo University, Giza, Egypt. \\ E-mail:erhamed@yahoo.com
}

Received 2 July 2008; received in revised form 26 February 2009; accepted 26 February 2009

\begin{abstract}
Nineteen strains of microorganisms were screened for uricase production. Gliomastix gueg was recognized to produce high levels of the enzyme. The optimum fermentation conditions for uricase production by Gliomastix gueg were examined. Results showed that uric acid medium was the most favorable one, the optimum temperature was at $30^{\circ} \mathrm{C}$, and incubation period required for maximum production was 8 days with aeration level at $150 \mathrm{rpm}$ and at $\mathrm{pH} 8.0$. Sucrose proved to be the best carbon source, uric acid was found to be the best nitrogen source. Both, dipotassium hydrogen phosphate and ferrous chloride as well as some vitamins gave the highest amount of uricase by Gliomastix gueg.
\end{abstract}

Keywords: Gliomastix gueg, uricase production, physiological conditions

\section{INTRODUCTION}

Urate oxidase or uricase (urate: oxygen oxidoreductase, EC 1.7.3.3) is an enzyme that catalyse the oxidation of uric acid to allantoin and plays an important role in purine metabolism (Wu et al., 1994). This enzyme is widely present in most vertebrates but is absent in humans (Schiavon et al., 2000). It was first found in bovine kidney. Various natural sources such as bacteria (Mansour et al., 1996), fungi (Farley and Santosa, 2002) and eukaryotic cells (Montalbini et al., 1997) have also been found to be uricase producers. The first important application discovered for uricase was in clinical biochemistry as a diagnostic reagent for measurement of uric acid in blood and other biological fluids (Adamek et al., 1989). Higher primates (apes and humans) lack functional uricase and excrete uric acid as the end product of purine degradation (Friedman et al., 1985; Yeldandi et al., 1990). In some individuals, uric acid precipitates, leading to gout symptoms. Gout treatment generally includes allopurinol, which is a potent competitive inhibitor of xanthine dehydrogenase, an enzyme which catalyses the conversion of hypoxanthine to xanthine and xanthine to uric acid. However, in the case of gout associated with renal complications, direct injection of urate oxidase allows much more rapid resorption of urate nephrolithiases. Such injections are done to prevent or treat hyperuricemia disorders that may occur during chemotherapy.

Gout is a painful disorder, characterized by uricemia, recurrent attacks of acute arthritis, deposition of sodium urate in and around joints, and in many cases, formation of uric acid calculi (Lee et al., 1988).
Uricase was originally isolated from mammalian organisms. Recently interest was concentrated on microbial preparations from various fungi, yeast and bacteria. The microbial enzyme is inducible and therefore, the presence of uric acid or some other inducer in the medium is necessary for enzyme production (Adamek et al., 1989). Although several microbial sources of uricase have been proposed for this clinical indication, only one has actually been used commercially under the trade mark of uricozyme and is isolated and purified from Aspergillus flavus .

In various microorganisms uricase synthesis is regulated by components of the growth medium and the ability to degrade uric acid and to use it for growth is an inducible property of these microorganisms (Vander Drift and Vogels, 1975). Moreover, it was suggested that uricase formation might be controlled by a repression in which a metabolite derived from both the nitrogen and carbon sources may participate (Bongaerts et al., 1977).

Several investigators (Yazdi et al., 2006; Lotfy, 2008 ) studied the optimal temperature and $\mathrm{pH}$ for the production of uricase by microorganisms. The effect of various carbon and nitrogen sources on the formation of uricase by microorganisms was studied by several authors (Azab et al., 2005; Zhou et al., 2005; Yazdi et al., 2006; Lotfy, 2008).

The main purpose of this research is to screen the available local fungal strains for their uricase producing ability, to select the most potent isolate and also to optimize the culture conditions for maximum uricase production.

\section{*Corresponding author}




\section{MATERIALS AND METHODS}

\section{Organisms}

All strains investigated in this study were brought from the culture collection of the Department of Chemistry of Natural and Microbial Products at the National Research Center. The cultures were maintained on Czapek dox agar and stored at $\left(5\right.$ to $\left.6^{\circ} \mathrm{C}\right)$.

\section{Media}

Three different media were used for uricase production. Yeast extract sucrose medium: Sucrose $150.0 \mathrm{~g}$; yeast extract 20.0 g. (Davis et al., 1966). Czapek- Dox- medium: $\mathrm{NaNO}_{3} 2.0 \mathrm{~g} ; \mathrm{K}_{2} \mathrm{HPO}_{4} 1.0 \mathrm{~g} ; \mathrm{KCl} 0.5 \mathrm{~g} ; \mathrm{MgSO}_{4} 0.5 \mathrm{~g}$; $\mathrm{FeSO}_{4} .7 \mathrm{H}_{2} \mathrm{O} 0.01 \mathrm{~g}$ and sucrose $20.0 \mathrm{~g}$. (Huang and Ling, 1973). Uric acid medium: uric acid $1.0 \mathrm{~g} ; \mathrm{K}_{2} \mathrm{HPO}_{4} 1.0 \mathrm{~g}$; $\mathrm{MgSO}_{4} 0.5 \mathrm{~g} ; \mathrm{NaCl} 0.5 \mathrm{~g} ; \mathrm{FeSO}_{4} 0.01 \mathrm{~g}$ and sucrose 20.0 g. (Abdel Fattah and Abo hamed, 2002). Ingredient of each medium was dissolved in 1 liter distilled water and $\mathrm{pH}$ was adjusted to 6.5-7.0.

\section{Fermentation conditions}

Fifty $\mathrm{mL}$ aliquots of fermentation medium were dispensed in $250 \mathrm{~mL}$ Erlenmeyer conical flasks, inoculated with two discs (10 mm in diameter) from 7-day old cultures. The inoculated flasks were incubated on a rotatory incubator shaker at $150 \mathrm{rpm}$ for 8 days at $30{ }^{\circ} \mathrm{C}$ after which the mycelium of each isolate was collected by centrifugation at 5000 to $6000 \mathrm{rpm}$ for $15 \mathrm{~min}$ at $4{ }^{\circ} \mathrm{C}$. The cell free supernatant was used as a crude enzyme for further determinations.

\section{Enzyme assay}

Uricase activity was measured according to the procedure described by Adamek et al. (1989). To $2 \mathrm{~mL}$ of a solution containing uric acid (10ug per $\mathrm{ml}$ of borate buffer $0.2 \mathrm{M}$, $\mathrm{pH} 8.5), 0.8 \mathrm{~mL}$ of water and $0.1 \mathrm{~mL}$ of crude enzyme at $25{ }^{\circ} \mathrm{C}$ were added. After $10 \mathrm{~min}, 0.2 \mathrm{~mL}$ of $0.1 \mathrm{M}$ potassium cyanide solution was added to the mixture to stop the enzyme reaction. In the reference sample, the solution of potassium cyanide was added to the mixture before the addition of the crude enzyme. The absorbance of both samples was measured at $293 \mathrm{~nm}$. The difference between absorbance of the sample and reference is equivalent to the decrease in uric acid during the enzyme reaction. One unit of uricase enzyme was equal to the amount of enzyme which converts $1 \mu \mathrm{mol}$ of uric acid to allantoin per min at $30^{\circ} \mathrm{C}$.

\section{Factors affecting uricase production}

\section{Carbon sources}

Sucrose was omitted from uric acid fermentation media and replaced by $1 \%$ of each glucose, fructose, lactose, starch, cellulose and glycerol.

\section{Nitrogen sources}

Uric acid was omitted from uric acid fermentation medium and supplemented by $0.5 \%$ of $\mathrm{NaNO}_{3}, \mathrm{KNO}_{3},\left(\mathrm{NH}_{4}\right)_{2} \mathrm{SO}_{4}$, $\mathrm{NH}_{4} \mathrm{Cl}$, peptone and casein as a sole sources of nitrogen.

\section{Phosphate sources}

Different sources of phosphate $\left(\mathrm{KH}_{2} \mathrm{PO}_{4}, \mathrm{Na}_{2} \mathrm{HPO}_{4}\right.$ and $\mathrm{NaH}_{2} \mathrm{PO}_{4}$ ) have been added to the fermentation medium at a concentration equimolar to the concentration of the basal phosphate source $\left(\mathrm{K}_{2} \mathrm{HPO}_{4}\right)$.

\section{Elements}

Different elements such as $\mathrm{Ca}^{2+}\left(\mathrm{CaCl}_{2}\right), \mathrm{CO}^{2+}\left(\mathrm{COCl}_{2}\right)$, $\mathrm{Mn}^{2+}\left(\mathrm{MnSO}_{4}\right), \mathrm{Mg}^{2+}\left(\mathrm{MgSO}_{4}\right), \quad \mathrm{Fe}^{3+}\left(\mathrm{FeCl}_{3}\right), \mathrm{PO}_{4}^{3-}$ $\left(\mathrm{Na}_{2} \mathrm{HPO}_{4}\right), \mathrm{CN}^{-1}$ (Na CN), $\mathrm{I}_{3}$ (lodine) and $\mathrm{Hg}^{+2}\left(\mathrm{HgCl}_{2}\right)$ have been added to the culture medium at a concentration equimolar to the concentration of the basal element of the medium.

\section{Vitamins}

Some vitamins such as riboflavin, nicotinic acid, folic acid and ascorbic acid were added to the fungal culture at a concentration $1.0 \mathrm{~g} / \mathrm{L}$ of each vitamin and sterilized by filtration.

\section{Amino acid}

Addition of the individual amino acid at $1.0 \mathrm{~g} / \mathrm{L}$ of cysteine, cystine, arginine, glycine and tryptophane to the fungal culture. The $\mathrm{pH}$ was adjusted to 8.0.

\section{RESULTS AND DISCUSSION}

\section{Selection of fungal strains for uricase production}

The aim of this experiment was to select the fungal strain which able to produce the highest amount of uricase. The nineteen fungal strains were inoculated in yeast extract sucrose medium at $\mathrm{pH} 6.5$ and incubated for 7 days in an incubator shaker at $150 \mathrm{rpm}$ and $30^{\circ} \mathrm{C}$.

Results in Table 1 show that all tested strains produced uricase enzyme. The two strains belonging to Gliomastix gueg (NRC1A) and Gliocladium virens (NRC24SH) proved to have higher uricase producing potential 275.98 and $233.90 \mathrm{U} / \mathrm{mL}$ respectively, followed by Alternaria solani (NRC10) (177.67 U/mL) and Aspergillus niger (NRC4) (164.98 U/mL). Chalaropsis sp. (NRC4A) produced less amount of uricase (17.69 U/mL). From the obtained results Gliomastix gueg (NRC1A) was selected for the subsequent experiments.

\section{Fermentation medium}

Two disks of $G$. gueg (NRC1A) were inoculated in 250 conical flasks containing $50 \mathrm{~mL}$ of each of the following medium: uric acid, Czapek dox and yeast extract sucrose. 
The inoculated flasks were incubated at $30{ }^{\circ} \mathrm{C}$ on an incubator shaker (150 rpm) for 8 days at $\mathrm{pH} 8.0$.

The results in Table 2 showed that uric acid medium was the most favorable medium for uricase production (1343.99 U/mL), while Czapek dox medium $(535.15 \mathrm{U} / \mathrm{mL})$ was the lowest one. This may be due to that several fungi can utilize uric acid as a sole source of nitrogen or to satisfy their requirements of nitrogen and carbon. These results were in confirmity with what obtained by Lookwood and Garrison (1968).

Table 1: Uricase enzyme activity by different fungal strains

\begin{tabular}{ll}
\hline Fungal strains & $\begin{array}{l}\text { Uricase } \\
\text { activity } \\
(\mathrm{U} / \mathrm{mL})\end{array}$ \\
\hline Acremonium zonatum (NRC12P) & 39.45 \\
Alternaria solani (NRC4P) & 57.59 \\
A. solani (NRC10) & 177.67 \\
A. teneus (NRC13P) & 45.26 \\
Aspergillus awamori (NRC32) & 53.86 \\
A. candidus (NRC15) & 126.88 \\
A. flavus (NRC16) & 71.39 \\
A. flavus (NRC17) & 131.60 \\
A. niger (NRC4) & 164.98 \\
Blastomyces cost (NRC16P) & 46.71 \\
B. dermatitides (NRC1) & 45.98 \\
Chalaropsis sp. (NRC4A) & 17.69 \\
Cladosporium macrocarpum (NRC9A) & 88.06 \\
Gliocladium virens (NRC24SH) & 233.90 \\
Gliomastix gueg (NRC1A) & 275.98 \\
Gonatorrhodiella parasitica (NRC40) & 131.89 \\
Martensiomyces pterosporus (NRC27) & 57.00 \\
Scopulariopsis candida (NRC7A) & 40.18 \\
S. fusca (NRC6A) & 30.82 \\
\hline
\end{tabular}

Table 2: Effect of different fermentation media on uricase production by Gliomastix gueg (NRC1A)

\begin{tabular}{ll}
\hline Fermentation media & Uricase activity $(\mathrm{U} / \mathrm{mL})$ \\
\hline Uric acid & 1343.99 \\
Czapek dox & 535.15 \\
Yeast extract sucrose & 876.74 \\
\hline
\end{tabular}

\section{Temperature}

An experiment was designed to determine the optimum temperature for fungal growth to produce high quantity of uricase enzyme. Uric acid medium was inoculated with the fungal strain, maintained on an incubator shaker at different degrees of temperature $(26,28,30,32$, and $35{ }^{\circ} \mathrm{C}$ ) for 8 days at $\mathrm{pH}$ 6.5. Results given in Figure 1 show that uricase production increased as incubation temperature increased until reached maximum (141.76 $\mathrm{U} / \mathrm{mL}$ ) at $30^{\circ} \mathrm{C}$ and then decreased. These results were in agreement with those of Ammar et al. (1988), Tohamy and Shindia (2001), Abd El Fattah and Abo Hamed (2002) and Yazdi et al. (2006) who found that the optimum temperature for uricase production was $30^{\circ} \mathrm{C}$.

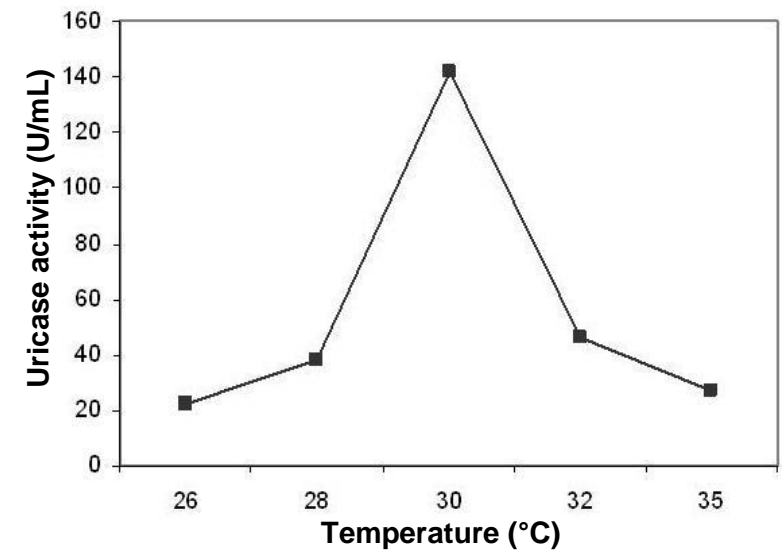

Figure 1: Effect of Different temperatures on uricase enzyme production

\section{pH}

The purpose of this experiment was to determine the optimum $\mathrm{pH}$-value of fermentation medium suitable for uricase production. Gliomastix gueg (NRC1A) was inoculated in fermentation medium adjusted at different $\mathrm{pH}$ values (5.0, 5.5, 6.0, 6.5, 7.0, 7.5, 8.0, 8.5 and 9.0). All complementary methods were adopted as mentioned before. Results presented in Figure 2 show that the optimal $\mathrm{pH}$ for uricase production $(521.22 \mathrm{U} / \mathrm{mL})$ by $G$. gueg (NRC1A) was $\mathrm{pH}$ 8.0. More or less than this point decreased uricase production. These results coincided with those of Greene and Mitchell (1957) who produced uricase from Neurospora crassa at $\mathrm{pH} 8.8$, but they were slightly in agreement with those of Tohamy and Shindia (2002) and Yazdi et al (2006) who found that $\mathrm{pH} 6.0$ was optimum for uricase production from A. flavus and Mucor hiemalis, respectively. Thapar et al (1975) showed that the highest production of uricase by $A$. wentii was at $\mathrm{pH}$ 10. In this connection, the optimum $\mathrm{pH}$ for uricase production by $A$. flavus $\mathrm{S} .79$ was reported at $\mathrm{pH} 9.2$ (Ammar et al., 1988).

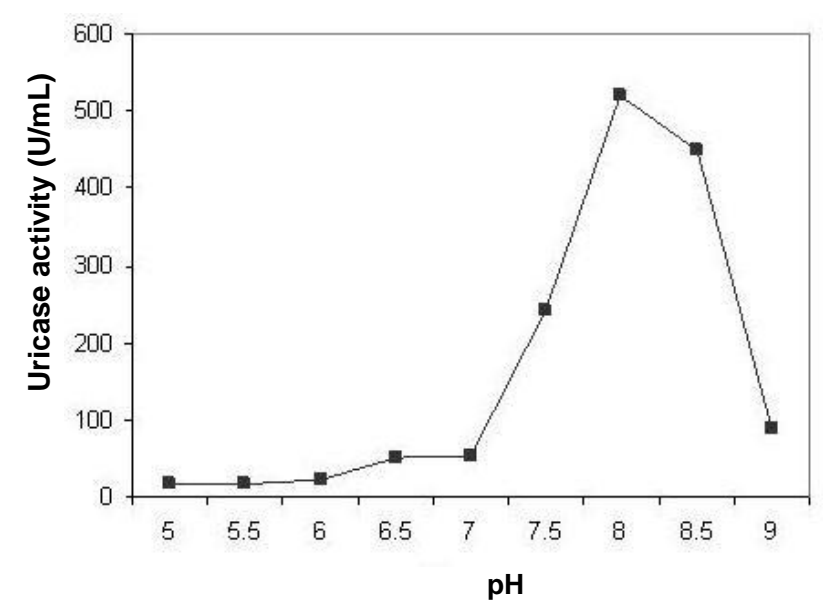

Figure 2: Effect of initial pH value of the medium on uricase enzyme production 


\section{Aeration level}

It was economically important to examine the role of aeration level on uricase production in the fermentation medium. From the results recorded in Figure 3, it was observed that increasing aeration level was in favour of more uricase production and reached maximum (804.19 $\mathrm{U} / \mathrm{mL}$ ) at $150 \mathrm{rpm}$, then decreased upon increasing the agitation speed (81.54 U/mL). Such finding was also obtained by Azab et al. (2005) who found that uricase was produced by Proteus vulgaris in submerged fermentation flasks on an incubator shaker at $180 \mathrm{rpm}$.

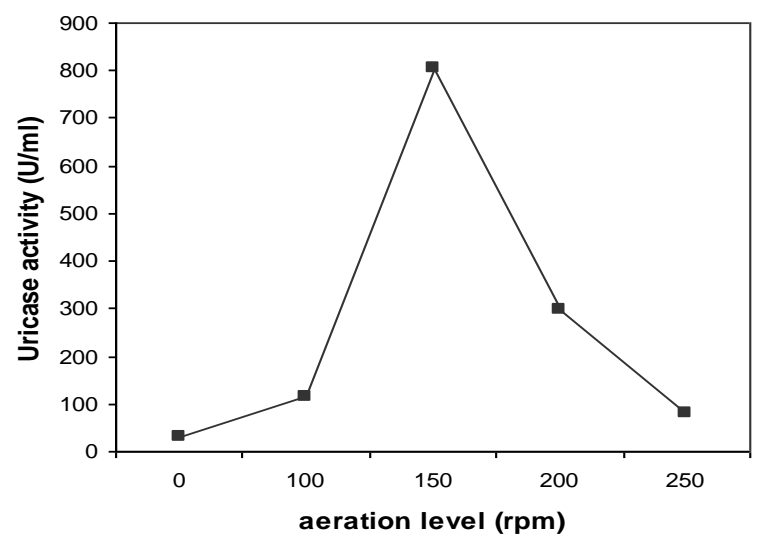

Figure 3: Effect of different aeration levels on uricase enzyme production

\section{Carbon sources}

This experiment was designed to select the favorable carbon source for uricase production. The results in Figure 4 show that the highest amount of uricase enzyme (1133.19 U/mL) was produced in the medium containing sucrose. These results were in agreement with those of Abd El Fattah and Abo Hamed (2002) who showed that $A$. flavus produced the highest amount of uricase in the medium containing sucrose.

\section{Nitrogen sources}

The present experiment was conducted to test the suitability of different nitrogen sources for uricase production. The results presented in Figure 5 show that $G$. gueg (NRC1A) recorded highest amount of uricase $(1133.19 \mathrm{U} / \mathrm{mL})$ when the fermentation medium contained uric acid. Similar results were obtained by other workers i.e. Yazdi et al. (2006) and Abd El Fattah and Abo Hamed (2002), who produced uricase in medium containing uric acid as a sole nitrogen source.

\section{Phosphours sources}

The results presented in Figure 6 show that dipotassium hydrogen phosphate gave the highest amount of uricase (1133.19 U/mL). It was obvious that potassium phosphate is more suitable than sodium phosphate. These results were disagree with those of Abd El Fattah et al. (2005) who found that $\mathrm{KH}_{2} \mathrm{PO}_{4}$ gave the highest amount of uricase as compared with $\mathrm{K}_{2} \mathrm{HPO}_{4}$. Hydrogen ion plays an important role for the acidic range balance.

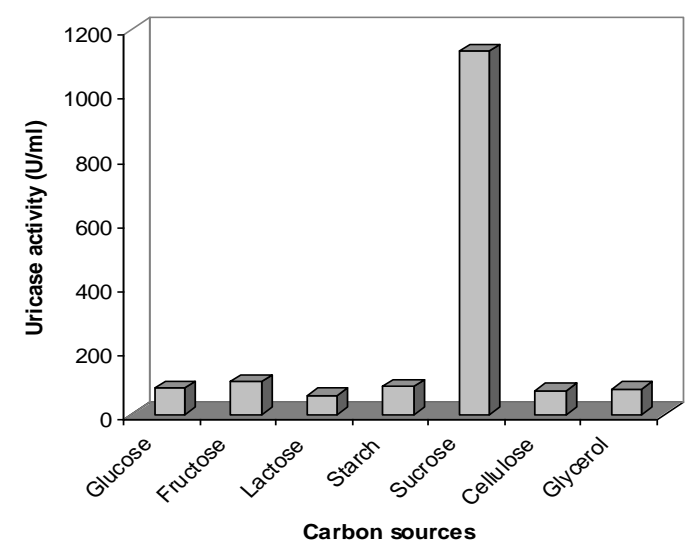

Figure 4: Effect of different carbon sources on uricase enzyme production

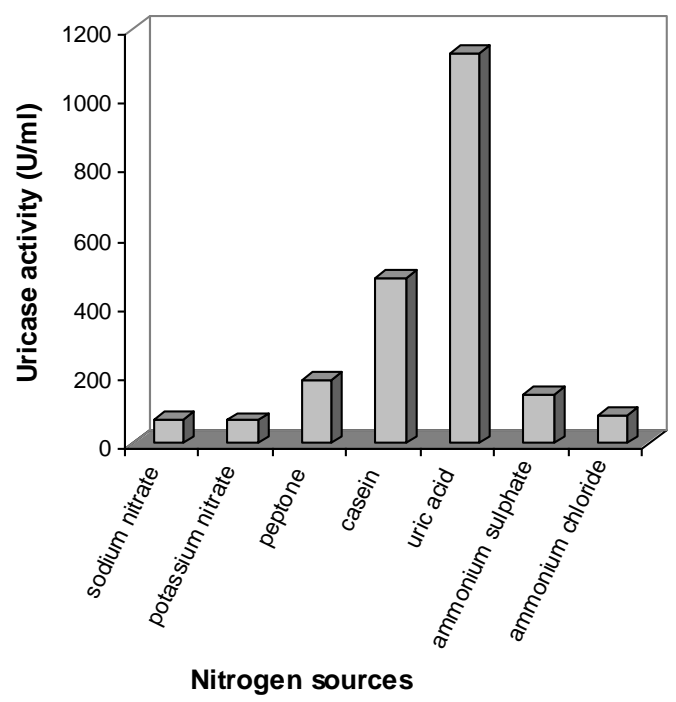

Figure 5: Effect of different nitrogen sources on uricase enzyme production

\section{Incubation period}

The goal of this experiment was to select the optimum incubation period for uricase production by $G$. gueg (NRC1A) when grown on uric acid medium at $30^{\circ} \mathrm{C}$ under shaken conditions for different periods of time. Results in Table 3 indicated that 8 days incubation was optimum for uricase production by $G$. gueg (NRC1A). These results disagree with those of Abd El Fattah and Abo Hamed (2002) who produced uricase from A. flavus, Aspergillus terreus after 4 days incubation and from Trichoderma sp. after 6 days. Yukiko et al. (1976) produced maximum uricase by Hyphomyces after 5 days incubation. 


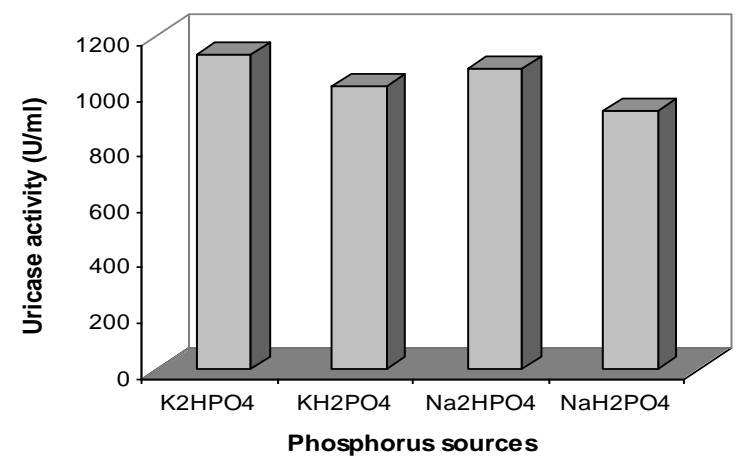

Figure 6: Effect of phosphorus sources on uricase enzyme production

Table 3: Effect of incubation period on uricase enzyme production by $G$. gueg (NRC1A)

\begin{tabular}{ll}
\hline $\begin{array}{l}\text { Incubation } \\
\text { period (days) }\end{array}$ & $\begin{array}{l}\text { Uricase activity } \\
\text { (U/mL) }\end{array}$ \\
\hline 2 & 85.89 \\
4 & 53.97 \\
6 & 64.12 \\
8 & 1343.99 \\
10 & 558.95 \\
12 & 239.71 \\
14 & 188.92 \\
16 & 17.69 \\
\hline
\end{tabular}

\section{Elements}

It is clear from Figure 7 that ferrous chloride gave the highest amount of uricase $(1574.72 \mathrm{U} / \mathrm{mL})$. On the other hand, sodium cyanide gave the less amount of uricase $(275.80 \mathrm{U} / \mathrm{mL})$.

\section{Vitamins}

Data presented in Figure 8 show that folic acid and ascorbic acid had a high stimulatory effect on uricase production by the experimental organism (1180.02 and $1169.87 \mathrm{U} / \mathrm{mL}$ ), respectively. Also, nicotinic acid and riboflavin appeared to stimulate uricase production but at a lesser extent (1053.78 and $1040.71 \mathrm{U} / \mathrm{mL}$, respectively). Such findings were obtained by Abd El Fattah and Abo Hamed (2002) who found that the production of uricase was hardly affected by the incorporation of most studied vitamins irrespective of the fungus. However, the addition of vitamin $\mathrm{C}$, molasses and vitamin $\mathrm{B}_{12}$ slightly stimulated this process in A. terreus, A. flavus and Trichoderma sp., respectively. They also demonstrated that addition of nicotinic acid, folic acid and riboflavin exhibited various inhibitory effects against uricase production.

\section{Amino acids}

It is clear from the results presented in Figure 9 that the presence of cystine in the medium gave the highest amount of uricase (1024.76 U/mL) followed by glycine (1011.69 U/mL). On the other hand tryptophane gave the lowest amount of uricase $(468.98 \mathrm{U} / \mathrm{mL})$.

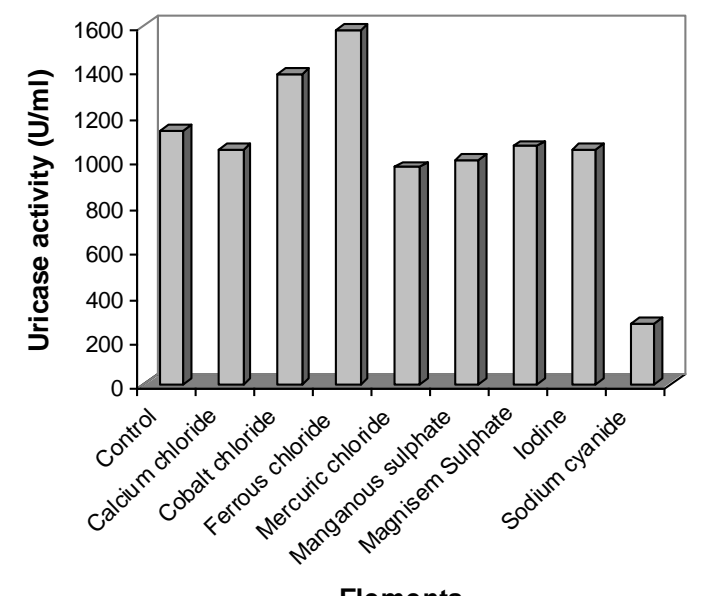

Figure 7: Effect of some elements on uricase enzyme production

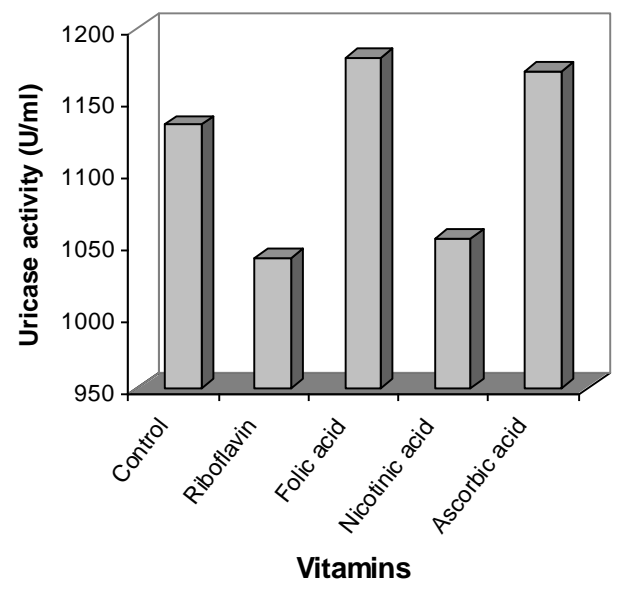

Figure 8: Effect of different vitamins on uricase enzyme production

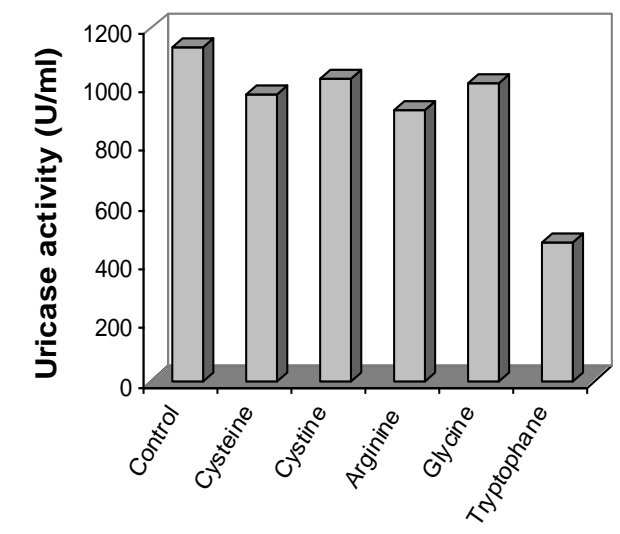

Amino acids

Figure 9: Effect of different amino acids on uricase enzyme production 


\section{REFERENCES}

Abd El Fattah, M. G. and Abo-Hamed, N. A. (2002). Bioconversion of poultry waste I - Factors influencing the assay and productivity of crude uricase by three uricolytic filamentous fungi. Acta Microbiologica and Immunologica Hungarica 49, 445-454.

Abd El Fattah, Y. R., Saeed, H. M., Gohar, Y. M. and ElBaz, M. A. (2005). Improved production of Pseudomonas aeruginosa uricase by optimization of process parameters through statistical experimental designs. Process Biochemistry 40, 1707-1714.

Adamek, V., Kralova, B., Suchova, M., Valentova, 0. and Demnerova, K. (1989). Purification of microbial uricase. Journal of Chromatography 497, 268-275.

Ammar, M. S., Elwan, S. H. and El-Desouky, E. M. (1988). Purification and some properties of uricase from Aspergillus flavus S-97. Egyptian Journal of Microbiology 23, 83.

Azab, E. A., Ali, M. M. and Fareed, M. F. (2005). Studies on uricase induction in certain bacteria. Egyptian Journal of Biology 7, 44-54.

Bongaerts, G. P. A., Sin, L. I., Peters, J. L. J. and Vogels, D. G. (1977). Purine degradation in $P$ seudomonas aeruginosa and Pseudomonas testosterone. Biochimica et Biophysica Acta 499, 111-118.

Davis, N. D., Diener, U. L. and Eldridge, D. W. (1966). Production of aflatoxins $\mathrm{B}_{1}$ and $\mathrm{G}_{1}$ by Aspergillus flavus in a semisynthetic medium. Applied Microbiology 14, 378-380.

Farley, P. C. and Santosa, S. (2002). Regulation of expression of the Rhizopus oryzae uricase and urease enzyme. Canadian Journal of Microbiology 48, 1104-1108.

Friedman, T. B., Polanco, G. E. Appold, J. C. and Mayle, J. E. (1985). On the loss of uricolytic activity during primate evalution. I. Silencing of urate oxidase in a hominoid ancestor. Comparative Biochemistry and Physiology 81B, 653-659.

Greene, R. C. and Mitchell, H. K. (1957). Uricase in Neurospora crassa. Archives of Biochemistry and Biophysics 70, 603-613.

Huang, J. C. and Ling, K. H. (1973). Isolation and identification of a toxic hydrophilic metabolite from the culture broth of Penicillium sp. 171. Journal of the Formosan Medical Association 72, 649-657.

Lee, C. C., Wu, R. A., Giggs, R. G., Cook, Muzny, D. M. and Caskey, T. (1988). Generation of cDNA probes directed by amino acids sequence: cloning of urate oxidase. Science 293, 1288-1291.

Lookwood, G. F. and Garrison, R. G. (1968). The possible role of uric acid in the ecology of Histoplasma capsuatum. Mycopathol. Mycol. Appl. 35, 377.

Lotfy, W. A. (2008). Production of thermostable uricase by a novel Bacillus thermocatenulatus strain. Bioresource Technology 99, 699-702.

Mansour, F. A., Nour- El- Dein, M. M., El- Fallel, A. A. and Abou-Do-Bara, M. I. M. (1996). Purification and general properties of uricase from Streptomyces aureomonopodiales. Acta Microbiologica Polonica 45, 45-53.

Montalbini, P., Redondo, J., Caballero, J. L., Cardenas, J. and Pineda, M. (1997). Uricase from leaves: its purificación and characterization from three different higher plants. Planta Heidelberg 202, 277-283.

Schiavon, O., Caliceti, P., Ferruti, P. and Veronese, F. M. (2000). Therapeutic proteins: a comparison of chemical and biological properties of uricase conjugated to linear or branched poly (ethylene glycol) and poly (Narryloylmorpholine). II Farmaco 55, 264-269.

Thapar, V. K., Sethi, R. P. and Rattan, S. (1975). Studies on fungal uricase extraction, purification and properties. Jers. Punijab Agric Univ. 12, 62.

Tohamy, E. Y. and Shindia, A. A. (2001). Partial purification and some properties of uricase produced by strain of Aspergillus terreus. Egyption Journal of Microbiology 36, 77-87.

Vander Drift, L. and Vogels, D. C. (1975). Allantoin racemase: a new enzyme from Pseudomonas species. Biochimica et Biophysica Acta 391, 240-248.

Wu, X., Wakamiya, M., Vaishnav, S., Geske, R., Montgomery, C., Jones, P., Bradley, A. and Caskey, T. (1994). Hyperuricemia and urate nephropathy in urate oxidase deficient mice. Proceedings in Natural Academy Science of USA 91, 742-746.

Yazdi, M. T., Zarrini, G., Mohit, E., Faramarzi, M. A., Setayesh, N. and Mohseni, F. A. (2006). Mucor hiemalis: a new source for uricase production. World Journal of Microbiology and Biotechnology 22, 325330.

Yeldandi, A. V., Wang, X., Alvares, K., Kumar, S., Rao, M. S. and Reddy, J. K. (1990). Human urate oxidase gene: colning and partial sequence analysis reveal a stop codon within the fifth exon. Biochemical and Biophysical Research Communications 171, 641-645.

Yukiko, K. Yayoi, D. and Hakuy, K. (1976). The characteristics of uricase production by Hyphomycetes II. The effectiveness of purines and pyrimidines as substrate. Yakugaku Zasshi, Japan 96, 377.

Zhou, X., Ma, X., Sun, G., Li, X. and Guo, K. (2005). Isolation of a thermostable uricase producing bacterium and study on its enzyme production conditions. Process Biochemistry 40, 3749-3753. 